\title{
Elektronisk vurdering er effektivt for studenter i praksisstudier
}

Et elektronisk studentverktøy kan fremme læringsmiljøet for studenter i veiledet praksis. De får flere og mer presise tilbakemeldinger og en lett tilgjengelig oversikt over læringsmål og -aktiviteter.

Anne Grethe Kydland

Førstelektor

Seksjon for sykepleie, Høgskolen i Innlandet, Elverum

Solveig Struksnes

Dosent

Institutt for helsevitenskap, NTNU, Gjøvik

Siv Sønsteby Nordhagen

Førstelektor

Institutt for helsevitenskap, NTNU, Gjøvik

Fred Morten Solbakken

IKT Virksomhetsarkitekt

Sykehuset Innlandet, Brumunddal

Ingeborg Rustad

Assisterende avdelingssykepleier

Kirurgisk avdeling H4, Sykehuset Innlandet, Hamar

Martha H. Høvik

Spesialsykepleier

Nevrologisk avdeling, Sykehuset Innlandet, Lillehammer 


\section{Hovedbudskap}

Elektronisk studentvurdering (ESV) er et effektivt verktøy for å veilede og gi tilbakemeldinger til sykepleierstudenter i praksis. Et pilotprosjekt viser at sykepleiere og lærere er mer samstemte om hva som forventes av studentene, og gir flere og mer konstruktive tilbakemeldinger. Ved å benytte ESV blir det enklere for sykepleiere å gi feedback som en integrert del av arbeidsoppgavene.

Sykehuset Innlandet, NTNU i Gjøvik og Høgskolen i Innlandet gjennomførte i 2017-19 et samarbeidsprosjekt om å utprøve et elektronisk verktøy (ESV) for vurdering av studenter i praktiske studier i sykepleie.

Motivasjonen for å prøve ut et nytt verktøy er todelt: behovet for å utdanne flere sykepleiere og behovet for høy kvalitet på veiledning og vurdering av sykepleierstudenter $\mathrm{i}$ praksisstudier.

\section{Det er behov for kvalifiserte veiledere}

Norge vil ha behov for flere sykepleiere for å kunne møte den demografiske utviklingen med stadig flere eldre. En bachelorgrad i sykepleie består av 50 prosent teori og 50 prosent praktiske studier. Skal det utdannes flere sykepleiere, betyr det at antall praksisplasser med kvalifiserte veiledere må økes.

I realiteten er det mangelen på kvalifiserte veiledere som begrenser opptak av flere sykepleierstudenter. Vi kan altså argumentere for at praksisplasser er en flaskehals for å ta inn flere studenter på høyskolene og universitetene.

Når studentene er i praksis, forventer de veiledning og tilbakemeldinger. I en hektisk sykehushverdag kan det være vanskelig å få tid til disse oppgavene, da sykepleiere må prioritere pasienter foran studenter.

Det er viktig for studentenes læring at de får en tilbakemelding på det de har utført $(1,2)$. Tilbakemeldinger bør være relatert til hva som er forventet av studentene på det aktuelle nivået.

\section{三 «Utdanningsinstitusjonens dokumenter er både lite tilgjengelige og vanskelige å forstå for veilederne.»}


Vår erfaring og forskning viser at studenter opplever at lærere og veiledere ikke har de samme forventningene til hva som skal læres, og at utdanningsinstitusjonens dokumenter både er lite tilgjengelige og vanskelige å forstå for veilederne (3-5).

Et annet forhold som kompliserer veiledningsarbeidet for sykepleiere i praksis, er at samme avdeling kan ha studenter på ulike nivåer i utdanningen samtidig. Sykepleierne må dermed forholde seg til ulike læringsmål i sin veiledning.

For å kunne utdanne flere sykepleiere er det behov for gode og effektive verktøy som kan medvirke til at veilederne kan effektivisere og kvalitetssikre arbeidet med å gi studentene konstruktive og relevante tilbakemeldinger.

\section{Studentene ønsker å bli sett}

Forskning viser at vurdering av sykepleierstudenter i praktiske studier er et problemområde både nasjonalt og internasjonalt (6). Westad fant i sin forskning at sykepleiere synes det er et stort ansvar å veilede studenter, og at de har liten tid til slik veiledning (7).

I en studie om praksisveiledning av sykepleierstudenter kom det frem at studentene $\varnothing$ nsker å bli «sett». De stilte spørsmål ved lærernes mulighet til å vurdere studenter i praksis, da de sjelden er til stede i avdelingen.

Studien påpekte at når veilederne var syke eller hadde fri/ferie, kunne det medføre at studentene ikke fikk tilbakemelding. Andre sykepleiere overtok ikke automatisk ansvaret med å følge opp studentene i slike tilfeller (8).

\section{三 «Sykepleierstudenter synes at kvaliteten på praksisstudiene er god hvis de får konstruktive tilbakemeldinger.»}

Det er et faktum at tilbakemelding er viktig for læring. Sett i

lys av at sykepleiere har mange oppgaver, kan det synes viktig å legge til rette for at veiledning og tilbakemelding blir en integrert del av hverdagens oppgaver for sykepleiere. 
Det er et kjennetegn på et godt læringsmiljø at

forventningene mellom sykepleieren, læreren og studenten er

avklart, og at studenten får veiledning og relevante

tilbakemeldinger $(1,8,9)$. Ivarjord og Kitzmüller fant i sin

studie at sykepleierstudenter synes at kvaliteten på

praksisstudiene er god hvis de får konstruktive

tilbakemeldinger (10).

Hensikten med vår studie er å vurdere om bruk av elektronisk studentvurdering kan fremme læringsmiljøet og bidra til å redusere sykepleieres arbeid med veiledning og

tilbakemeldinger til studenter (9).

\section{Single-System Designs viser studentens nivå}

ESV er basert på en vurderingsmal hvor læringsutbyttene er beskrevet som læringsaktiviteter som studentene skal utføre. En nivåinndeling gjør det tydelig for veilederen hva som forventes av studenten.

ESV inneholder åtte kategorier for ulike læringsaktiviteter som studentene skal arbeide med i praksis:

- kunnskaper

- ferdigheter

- medikamenter

- sykepleieprosessen

- helsefremming

- samhandling

- hygiene

- etikk

Vurderingen av læringsutbyttene har vi gjort etter SingleSystem Designs.

\section{Single-System Designs}

En grafisk fremstilling av graden av et måloppfyllelseskriterium.

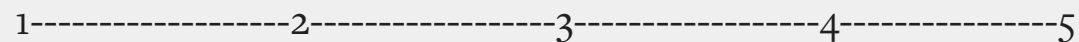

$\begin{array}{llll}\text { Ingen } & \text { Noe } & \text { Passe } & \text { Sterk }\end{array}$

Tydeliggjøring av oppnådd læringsutbytte: 
Single-System Designs er et system å for å kunne angi i hvilken grad

læringsutbyttet (målet) er oppnådd. Grunntanken med et slikt system er at det skal beskrive et forløp ved hjelp av grafiske illustrasjoner (11).

Når vi benytter dette designet, kan vi se i hvilken grad studenten har oppnådd målene ved hjelp av nivåinndelinger. Designet sier noe om graden av måloppnåelse og beskriver læring ved hjelp av ulike nivåer (11). For eksempel er «Tilfredsstillende» («T») nivået som forventes ved sluttvurderingen av studenten for å få bestått praksis (6).

Malen har følgende nivåinndeling:

- LT: Lite tilfredsstillende

- NT: Nokså tilfredsstillende

- T: Tilfredsstillende

- MT: Meget tilfredsstillende

- ST: Svært tilfredsstillende

Vi har utarbeidet vurderingskriterier i alle kategoriene for hver praksisperiode med $\varnothing$ kende progresjon fra første til tredje praksisperiode på sykehus. For å sikre progresjon fra første til andre og tredje praksisperiode har vi tatt utgangspunkt i beskrivelsen av nivået «T».

Vi har satt beskrivelsen av «T» inn i en tabell som viser hver enkelt kategori i de tre sykehuspraksisene som studentene skal igjennom. Tabell 1 er utarbeidet for å synliggjøre studentens progresjon i praksis.

Beskrivelsen av hva som er forventet ved måloppnåelse, skal være lett å forstå og bruke for å vurdere studenten. Se tabell 1.

I pilottestingen av ESV har vi vurdert beskrivelsene i de ulike syklusene kontinuerlig. Vi har endret vurderingskriteriene underveis slik at de er robuste og tydelige som ledd i en kvalitetssikringsprosess. 


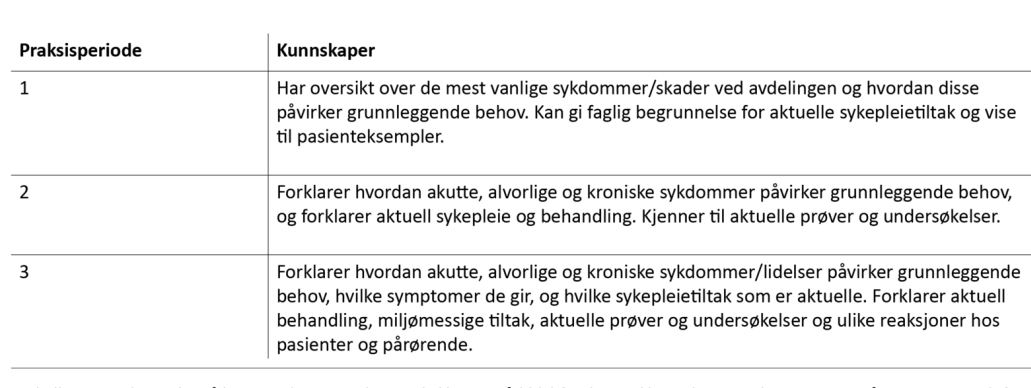

Tabellen viser eksempler på læringsutbytter studenten skal ha oppnådd (T) for de tre ulike praksisperiodene. Her er nivåene sammenstilt for ås synliggjøre studentens forventede progresjon for å få bestått praksis.

\section{Veiledere markerer studentenes nivå}

Rent praktisk er ESV merket som et ikon som alle sykepleiere og studenter får opp ved innlogging på sin jobb-PC.

Studentene markerer hvilke(n) kategori(er) de vil arbeide med den aktuelle dagen, og skriver en egenvurdering av læringsaktiviteter i den aktuelle kategorien.

Veilederen kan gi tilbakemelding ved å markere nivået («LT», «NT», «T», «MT», «ST»), skrive en kommentar eller begge deler. Se figur 1.

Figur 1. Eksempler på kategorier i ESV

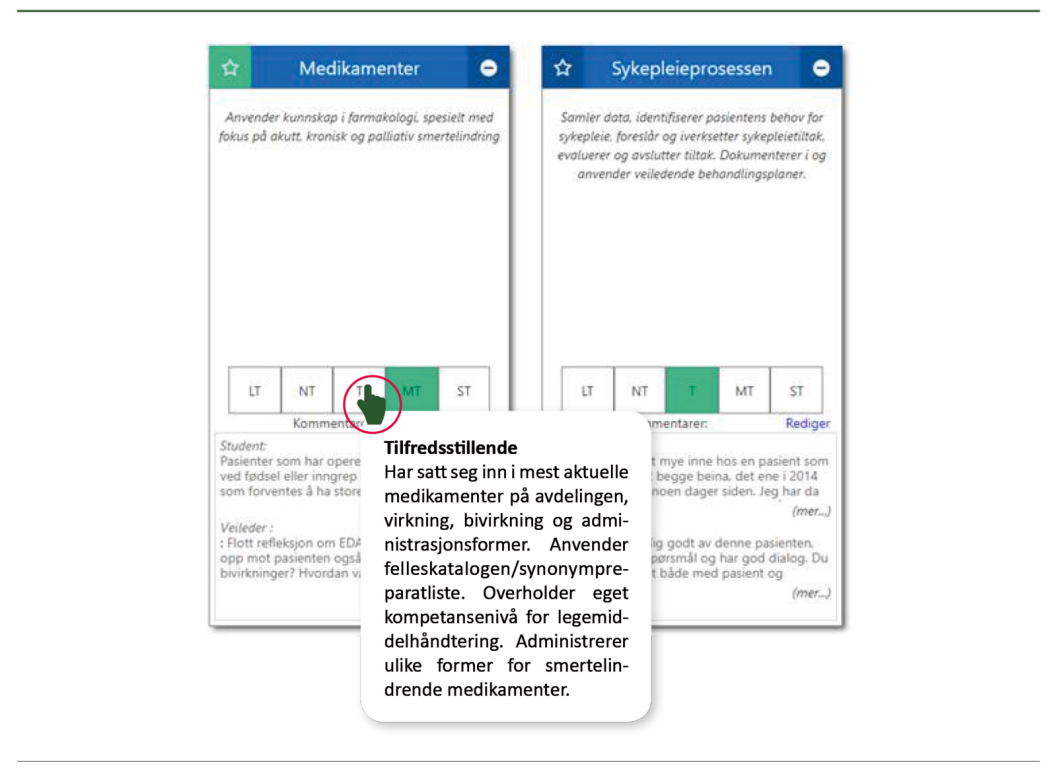

Eksempler på to kategorier i ESV med student- og veilederkommentarer. «Mouse-over» på nivåene synliggjør kriteriene.

Når veilederen markerer hver enkelt kategori med et nivå mellom «LT» og «ST», synliggjøres kriteriene som gjelder for den aktuelle studenten (figur 1). Studenten skriver egenvurdering daglig samt midt- og sluttvurdering.

Alle tilbakemeldinger blir lagret med dato og signatur og danner grunnlaget for midt- og sluttvurdering. Både studenten og veilederen kan logge seg inn i ESV gjennom mobiltelefonen sin (figur 1). 
Nedenfor er et eksempel på nivåer for samtaler som en student har hatt med pasienter (figur 2).

Figur 2. Nivåangivelse i kategorien «Ferdigheter»

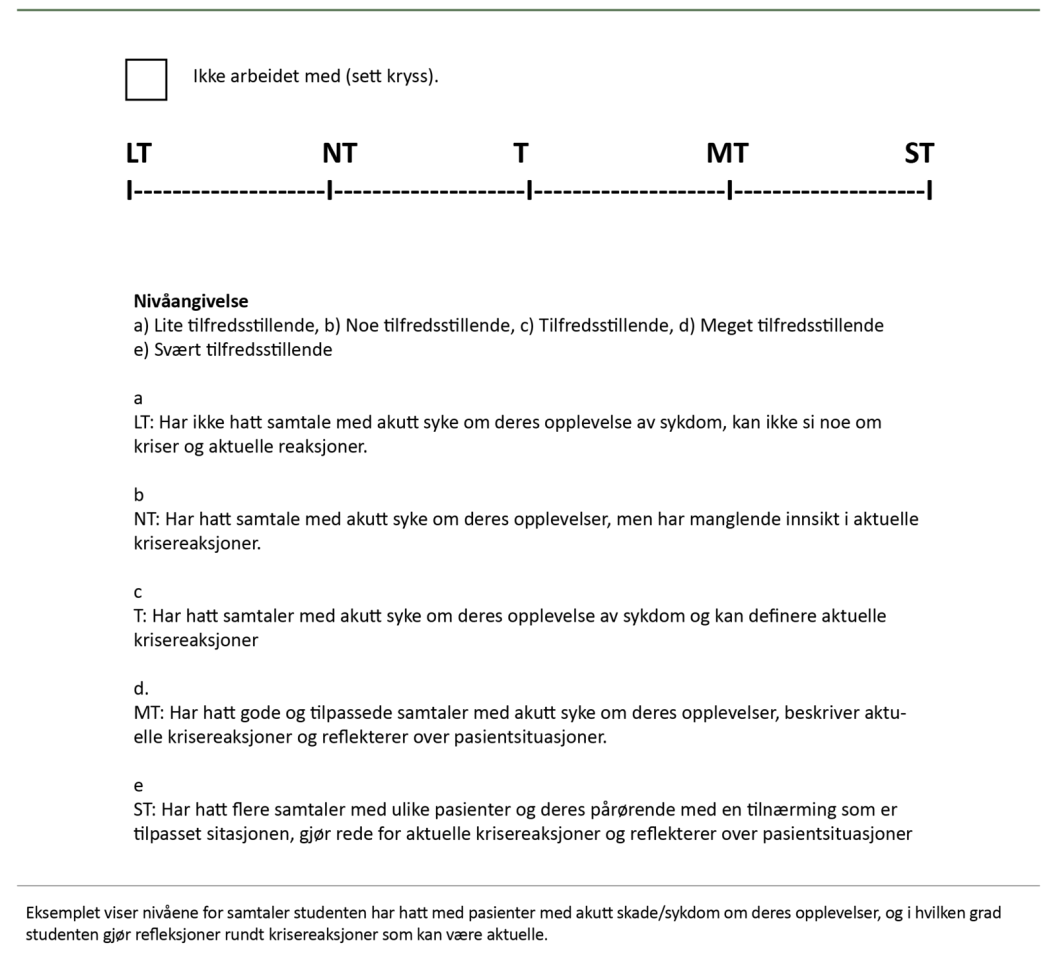

I ESV-verktøyet kan veilederen gi løpende formative og summative tilbakemeldinger underveis og en oppsummert vurdering midtveis som skal bidra til å tydeliggjøre hvordan studenten kan oppnå forventet læringsutbytte.

Til slutt gjør veilederen, læreren og studenten en samlet vurdering opp mot hva det er forventet at studenten skal oppnå for perioden (11-13).

\section{Prosjektet evalueres etter praksis}

Studenter, veiledere, avdelingsledere og lærere er rekruttert tilfeldig. Pilotprosjektet har utarbeidet en plan for utprøving av ESV i ulike avdelinger på Sykehuset Innlandet. Alle studenter, veiledere, avdelingsledere og lærere som har vært på de aktuelle avdelingene, har blitt invitert til å delta i prosjektet.

Prosjektet har blitt evaluert gjennom et spørreskjema som i etterkant av hver praksisperiode ble sendt til alle studenter, veiledere, lærere og avdelingssykepleiere som har testet ESV.

Spørreskjemaet er utviklet i Forms (Office 365) og består av Likert-skalerte holdningsutsagn fra $1-5$, hvor 1 betyr «Helt uenig» og 5 betyr «Helt enig». Spørsmålene omhandlet både innholdet og brukervennligheten i ESV. 
Informasjon om at deltakelsen var frivillig, og hvordan vi ivaretok informantenes anonymitet, sto på spørreskjemaets første side. Når informantene sendte inn spørreskjemaet, betraktet vi det som et samtykke til å delta.

Spørreskjemaet var tilpasset de ulike brukergruppene, og det ble distribuert via e-post. Alle svar ble returnert til prosjektdeltakerne i avidentifisert form.

\section{Studentene får bedre tilbakemeldinger}

Resultatene etter fire perioder med ESV viser at studentene (52) opplever at de får flere og mer presise tilbakemeldinger, og at veilederne og lærerne er mer samstemte i sine forventninger til studentene enn uten bruk av verktøyet.

ESV gir en oversikt over hvor mange og hvem av studentene som har fått tilbakemelding, og det er derfor lett å oppdage om noen studenter har få eller ingen tilbakemeldinger.

Verktøyet viser seg å gi god oversikt over aktuelle læringsaktiviteter og -mål, noe alle informantene påpeker. Det er også et funn i vår studie at studentene opplever å få flere tilbakemeldinger jo flere ganger ESV har blitt anvendt på avdelingen.

Sykepleierne opplever at de får bedre arbeidsflyt, og at de bruker mindre tid på dokumentasjonen når de har brukt ESV flere ganger.

\section{三 «Alle sykepleierne i den aktuelle avdelingen kan gi tilbakemelding om studentene i ESV.»}

De foreløpige resultatene etter fire perioder viser at studenter, veiledere, lærere og avdelingssykepleiere er overveiende positive til verktøyet. Aktuelle utfordringer studentene har, vil bli synliggjort gjennom tilbakemeldinger som er dokumentert i ESV.

Tilbakemeldingene underveis er signert og tidfestet og fremstår som en «logg» som kan legges til grunn for den summative midt- og sluttvurderingen. Alle sykepleierne i den aktuelle avdelingen kan gi tilbakemelding om studentene i ESV. 
Ved at veilederne bruker ESV, kan problemet med vurdering etter «skjønn» bli mindre, da kriteriene har som mål å være tydelige og lett tilgjengelige for å sikre relevante tilbakemeldinger til studentene.

\section{Konklusjon}

ESV er et verktøy som gjør læringsmålene tydelige på en lett tilgjengelig måte, både for studentene, veilederne og lærerne. Prosessen med å finne informasjon om hva som er forventet av studenten, er forenklet.

Å ha læringsmålene elektronisk og dermed lett tilgjengelig gjør det enklere for veilederne å gi relevante tilbakemeldinger. Når de benytter ESV, kan det bidra til at de tar felles ansvar for vurdering av studenter fordi det er enkelt å finne aktuell dokumentasjon om hva studentene har arbeidet med, og gi tilbakemeldinger på utførelsen.

Ved å bruke ESV kan flere sykepleiere ta ansvar for å gi tilbakemelding til studentene når eventuell kontaktsykepleier har fravær fordi verktøyet gir en lett tilgjengelig oversikt over læringsmål og -aktiviteter.

Dette er argumenter for at ESV kan fremme læringsmiljøet for studenter i veiledet praksis fordi de får flere tilbakemeldinger og opplever at veiledere og lærere er samstemte om hva som forventes av dem (1).

\section{三 «Det vil være et godt verktøy når studenttettheten $\emptyset$ ker.»}

ESV gir læreren mulighet til å lese studentens

tilbakemeldinger og egenvurderinger underveis uten å være fysisk til stede. Det kan medvirke til å kvalitetssikre midt- og sluttvurderingen fordi ESV gir læreren god oversikt over studentens aktiviteter.

Med utgangspunkt i våre erfaringer mener vi at innføring av ESV kan gjøre veiledning og vurdering av studenter i praksis enklere for sykepleiere. Det vil dermed være et godt verkt $\varnothing y$ når studenttettheten $\varnothing \mathrm{ker}, \mathrm{og}$ bidra til å kvalitetssikre vurderingsgrunnlaget samt fremme læring gjennom enighet om måloppnåelseskriterier. 
Alle tilbakemeldinger lagres i en samlet oversikt som er lett tilgjengelig for både studenter, veiledere og lærere. En slik oversikt gir mulighet til å få viktig informasjon, for eksempel data om hvilke kategorier studentene har problemer med å oppnå, eller hvilke kategorier de er gode på.

Etter vår mening vil en slik oversikt gi verdifull kunnskap for utdanningsinstitusjonen når det gjelder valg av satsing på eller endring av undervisning, slik at flere sykepleiere utdannes fordi flere oppnår forventet læringsutbytte.

\section{Referanser}

1. Kydland AGR, Høye S. Samspill mellom øvingsavdeling og praksis i sykepleie - mer læring? Nordisk sygeplejeforskning. 2015;5(1):75-83.

2. Øiestad G. Feedback. Oslo: Gyldendal Akademisk; 2004.

3. Alvsvåg $\mathrm{H}, \mathrm{F} \varnothing \mathrm{rland} \mathrm{O}$. Sykepleierutdanningen i lys av nyutdannedes yrkeserfaringer. Vård i Norden. 2006;26(3):348. DOI: $10.1177 / 010740830602600308$

4. Bjerknes MS, Christiansen B. Praksisveiledning med sykepleierstudenter. Oslo: Gyldendal Akademisk; 2015.

5. Ekman S, Fladeby N, Johansen I, Hardeland C, Leonardsen ACL. Hvordan kan sykepleierstudenter få det bedre når de er i praksis? Sykepleien. 2019;107(74902):e74902. DOI: $10.4220 /$ Sykepleiens.2019.74902

6. Kydland AGR, Nordström G. Nytt skjema er egnet til å vurdere praktiske studier i sykepleie. Sykepleien Forskning. 2018;13(74323):e-74323. DOI: 10.4220/Sykepleienf.2018.74323

7. Westad HK. Veilederes beveggrunner for å unnlate å gi ikke-bestått i praksisstudier til tross for at læringsutbyttene ikke er nådd. Scand J Caring Sci. 2015;35(1):20-8.

8. Bogsti WB, Solvik E, Engelien RI, Moen OL, Nordhagen SS, Struksnes S, et al. Strengthened supervision during clinical practice in nursing education. Vård i Norden. 2013;33(1):56-60. DOI: 10.1177/010740831303300112

9. Raaheim A. Læring og undervisning. Bergen:

Fagbokforlaget; 2011. 
10. Ivarjord L, Kitzmüller G. Veiledning av

sykepleiestudenter i klinisk praksis - hva anser sykepleiere

som viktig i utøvelsen av veilederrollen? Nordisk

sygeplejeforskning. 2019;9(01):6-19.

11. Eriksson BG, Karlsson P-Å. Att utvärdera välfärdsarbete.

Stockholm: Gothia; 2008.

12. Sverdrup S. Evaluering: tilnærminger, modeller og

eksempler. Oslo: Gyldendal Akademisk; 2014.

13. Taras M. Assessment - summative and formative - some theoretical reflections. Brit J Educ Stud. 2005;53(4):466-78.

DOI: $10.1111 / \mathrm{j} .1467-8527.2005 .00307 . \mathrm{X}$ 